\title{
A Sociolinguistics Study on the Use of the Javanese Language in the Learning Process in Primary Schools in Surakarta, Central Java, Indonesia
}

\author{
Kundharu Saddhono ${ }^{1} \&$ Muhammad Rohmadi $^{1}$ \\ ${ }^{1}$ Sebelas Maret University, Indonesia \\ Correspondence: Kundharu Saddhono, Sebelas Maret University, Jl. Ir. Sutami 36 Surakarta, Indonesia. E-mail: \\ kundharu.uns@gmail.com
}

Received: February 24, 2014

Accepted: April 8, 2014 Online Published: May 20, 2014

doi:10.5539/ies.v7n6p25

URL: http://dx.doi.org/10.5539/ies.v7n6p25

\begin{abstract}
This study aims at describing the use of language at primary schools grade 1, 2, and 3 in Surakarta. The study belongs to descriptive qualitative research. It emphasizes in a note which depict real situation to support data presentation. Content analysis is used as research methodology. It analyzes the research result of the observed speech event. The data are collected from three sources: informant, events, and documents. Results of the study demonstrate that the use of Javanese language is still dominant in the learning process at primary schools in Surakarta. Many factors affect the use of Javanese language as mother tongue in classroom teaching-learning process. They are (1) balancing the learning process, so that learners are able to better understand the material presented by the teacher (2) teacher's habit to speak Javanese language, and (3) drawing student's attention. The factors underlying this phenomenon are explained by teacher and student's lack of Indonesian language vocabulary. In addition, there is an element unnoticed by teachers.
\end{abstract}

Keywords: mother tongue, Javanese language, language use, primary school

\section{Introduction}

Language has become entrenched in human life particularly for its dominant function in communication. The use of language can be in the form of communication during teaching-learning process in classroom. Basically, learning language helps students to develop their self-awareness and cultures. Furthermore, language encourages students to express their opinions and feeling, to participate in social interaction, and to use their analytic and imaginative ability. Ohoiwutun (2002, p. 126) states that learning process in classroom shows a pattern of communication in multilingual society if we consider each variety representing one language. The main function of language in learning process is shown in 2013 curriculum, which put Indonesian language as the bridge between subjects.

Much research has been done on the use of language in primary schools such as in Brunei Darusallam by Martin (1996), in Papua New Guinea by Malone (2011), in Malaysia by Ariffin (2011), in Korea by Chung (2006), and in Africa by Ayeomoni (2006) and Jegede (2012). The research results generally show that mother tongue strongly influence student's utterance at school. It deals with children's limited language skill especially those in primary school. However, some factors influence the phenomenon of student's language in the learning process. Those factors can be internal, from the student, and external, from teacher and environment.

As the center of Javanese culture, Surakarta is dominated by Javanese language. It does happen at primary school grade 1,2, and 3 in which Javanese language often spoken during the learning process. According to Saddhono (2013), primary Schools in Surakarta regularly use both Javanese and Indonesian language. This happens, as Javanese language is the daily language of Javanese society, and in this case is teachers and students. Those two languages used interchangeably is in a language contact situation. This phenomenon is explained by Hamdani (2012) in a research on the use of Sundanese and Indonesian language, and in Muharam's (2012) research on Indonesian and Ternate Malay language.

The phenomenon shows that mother tongue's influence is dominant for students at primary school. This statement is proven by Pagett's (2006) research on the influence of mother tongue at school, and Malone's (2011) research. This speech event is recognized by the contact between mother tongue and language spoken at school. 
According to Weinreich in Suwito (1985, p. 39), language contact occurs in an individual speaker. Individuals in language contacts is called bilingual, and the use of two languages interchangeably by a speaker is called bilingualism. Bilingualism is important in the teaching-learning process to achieve effective and efficient result. The interaction between teacher and student in teaching-learning process usually use spoken language.

Communication during teaching-learning process is needed as student's interaction with teacher is very important. However, the proficiency of Indonesian language at primary schools is still difficult to determine as Indonesian language experience of students who are just starting school is also different in every area. It is triggered by the variety of mother tongue as their first language. Students who are younger than 7 or even children to enter school before compulsory school age has enough experience of Indonesian language. On the other side, there are also students with no Indonesian language experience. The disparity of student's Indonesian language proficiency triggers language mixing in the learning process. This paper will describe the phenomenon of the use of utterance at the primary schools in Surakarta by taking Javanese language as mother tongue into consideration.

\section{Research Methodology}

This research was conducted in Surakarta, Central Java, Indonesia. The subject of the research was students and teachers of grade 1, 2, and 3. The objects were taken for not mastering Indonesian language properly, both productive (writing and speaking) and receptive (reading and listening). Schools were chosen with specific consideration relates to status and affiliation, etc. This study belongs to descriptive qualitative research and emphasizes a note, which depict real situation to support data presentation (Sutopo, 2002, p. 36). Data were collected from three sources: informants, events, and documents. It incorporated content analysis technique. According to Holsti in Moleong (2002, p. 163), content analysis is any technique for making inferences by objectively and systematically identifying specified characteristics of messages. Sampling technique with particular consideration is called purposive sampling (Sugiyono, 2012). Similarly, Patton (1984) also states that in collecting the data, the selection of informant can change based on requirement and researcher's steadiness in collecting the data.

Data were collected by using technique of participation, observation, and conversation. Sample data was taken from the source of data, which are important and related to the observed problem. Data was collected by applying observation method, document analysis, and in-depth interview. The analysis of data employed interactive analysis method, which consists of three main components. They are data reduction, data presentation, and conclusion. Based on the data obtained, researcher develops the existing theory by using contextual approach, which is connected to speech component (Sudaryanto, 1995, p. 38).

\section{Research Result and Discussion}

The position of Surakarta as the center of Javanese culture, which is shown by the existence of Keraton Pura Mangkunegaran and Keraton Kasunanan Surakarta, has triggered the phenomenon of the use of Javanese language at primary schools in Surakarta. Preliminary research conducted by Saddhono (2013) shows that most of the students at primary schools in Surakarta has Javanese culture as their background. However, we can also find different ethnicities both from Indonesia and outside Indonesia.

Teacher usually uses Javanese language in daily conversation outside school, while Indonesian language is used in a formal situation such as meeting. In teaching-learning process, teachers use Indonesian language but student's lack of Indonesian vocabulary enforce teacher to mix Javanese and Indonesian language intentionally. That mixing has been an effective way in delivering information to students and to communicate with them. From that situation, code-switching and code-mixing occurs.

Speech event occurs in a private primary school in Surakarta is presented in the data which reflect the influence of Islamic Javanese culture, and informal language. The data implies that speech event occurs when teacher just starting the teaching-learning process.

(1) Guru

Teacher

Peserta Didik

Students

Guru

Teacher
Selamat pagi. Assalamualaikum warahmatullahi wabarakattuh.

Good Morning. Assalamualaikum warahmatullahi wabarakattuh.

Waalaikumsalam warahmatullahi wabarakattuh.

Baik, ada yang tidak masuk hari ini?

Okay, is there anyone who absent today? 


\section{Guru}

Teacher

Suryani

Speaker

Speech events

Speech topics

Purpose of speech

Location of : speech
Ada, Bu.

Yes, Miss.

Siapa?

Who?

Erna, Bu.

Erna, Miss.

Oh Mbak Erna. Kenapa gak masuk?

Oh Mbak Erna. Why is she absent?

Kemarin bilang katanya ke rumah mbahnya, Bu.

Yesterday, she said that she went to her grandmother's house, Miss.

Oh ke neneknya, dimana ya?

Oh, her grandmother's house. Where is it?

Jogja, Bu.

Jogja, Miss.

Speaker is a 3rd grade teacher with bachelor degree at a private primary school in Banjarsari District, Surakarta. She is 25 years old, Muslim, and single.

Hearer is students of the same class at private primary school in Banjarsari District. They are 22 students (boys and girls) with Javanese ethnicity.

The speech event is formal but casual as it occurs in a teaching-learning process at primary school.

Teacher starts the learning process by greeting the students. Then, she asks about students who are absent and why.

Teacher has purpose to greet students in starting classroom learning process and followed by a presentation about students who are absent and the reason of their absence.

The data shows a speech event conducted by teacher and students in starting classroom-learning process. In the event, teacher greets "Good Morning" which then followed by Assalamualaikum warahmatullahi wabarakatuh and answered by students with Waalaikumsalam warahmatullahi wabarakatuh. That greeting has been a tradition in Surakarta and even in Indonesia. It becomes a national greeting in a formal situation. Moreover, the speech occurs in a school with Islamic background. The greeting then followed by teacher's question about students who are absent. Wati as the class leader answers that Erna is absents for visiting her grandmother's house in Yogyakarta. In the speech event, it can be seen that Wati with Javanese language as her mother tongue tend to use Javanese language. She uses $m b a h$ that is in Indonesian language means "kakek/nenek" (grandparents) whereas she had better use eyang rather than mbah. Teacher also performs code-mixing in Javanese language. She uses mbak "sister" to call the student in order to express respect. That situation shows Javanese language as mother tongue is still used by its speaker in a formal situation. The use of Javanese language is influenced by some factors, both from speaker and hearer, as stated in a study by Saddhono $(2004,2007)$.

Many factors are behind the use of Javanese language by teacher in learning process. Teacher has to balance student's language skills so that student can better understand the information delivered by teacher. Teacher understands that student's skill in Indonesian language is still low, so she performs a mixing language, Indonesian and Javanese language. Students who do not understand the language performed by the teacher will be passive. It then encourages teacher to switch into Javanese language to counterbalance student's language skill. Teacher's habit to use Javanese language indeed influence her language skill at school as she performs Javanese language as her first language. However, that situation is also good to attract student's attention toward the lesson being taught.

The phenomenon of code-mixing and code-switching at primary school age in bilingual society is interesting. The role of mother tongue determine student's use of language. This study shows that Javanese language has been the dominant language. It is similar to the study conducted by Faltis (1989), Brice and Anderson (1999), 
and Gutiérrez-Clellen, Cereijido, and Leone (2009). Another study was also conducted by some researchers such as Gulzar (2010), David (2008) and Qing (2012). Although the research observed different languages, the phenomenon of code-mixing and code-switching are similar. It shows the important role of mother tongue in every speech event occurs at primary school.

This phenomenon is also described in a research conducted by Irawati (2012). She states that general characteristics of students' utterance in the first year of primary school are simple and concrete. Students also tend to use loanwords from their vernacular language. Consequently, some words and sentences are influenced by the pattern of the vernacular language. The conclusion of this study is viewed from the aspect of word classes, word formation, and sentence structure.

Yulianti (2013) concludes that code-mixing in teaching-learning process can be in the form of words, phrase, clause, and interference. Supporting factors are the similar language background between teacher and student, habit, environment, and comfort. Code-mixing helps students to understand teacher's explanation, to strengthen bonding between teacher and student, to encourage active learning such as responding, asking, and answering questions. Anwar (2013) conducted a more detailed research on analyzing the use of Javanese language by students at primary school. He observed more on the speech level in Javanese language ngoko and krama albeit some incorrect implementation of the language.

The push factor for teacher using Javanese language is student's lack of Indonesian vocabulary as Javanese is their daily language. Thus, teacher often use some Javanese terms in the learning process. Indeed, it aims at attracting student's attention to better understand teacher's explanation in class and the learning process run smoothly.

The use of Javanese language brings positive effect for the process of learning. Teacher who teach with Javanese and Indonesian language is more understood by students because not all students understand Indonesian language used by the teacher. Thus, the use of both Javanese and Indonesian language is more effective to deliver information and knowledge to students.

However, the mixing language brings negative effect as it ruins the grammatical aspect of Indonesian language. It is caused by the occurrence of code-mixing, code-switching, interference, and improper integration in the use of Indonesian language, which then create an informal situation. Code mixing and code switching also cause Indonesian language used improperly. Interference ruins the grammar whereas teacher should be able to introduce Indonesian language to students. In this case, teacher does not rigidly use the proper language so that students cannot develop their language skill better. Besides that, learning situation that should be formal become informal due to the code-mixing and code-switching done by the teacher.

\section{Conclusion}

According to the discussion, it can be concluded that the use of Indonesian language at the primary schools in Surakarta is still affected by Javanese language as the mother tongue and the daily language of People of Surakarta. Many factors influence the use of Javanese language in the learning process. Those factors are (1) to balance student's language skill so that the taught lesson can be easily understood, (2) teacher's habit to use Javanese language, and (3) to attract student's attention. Factor behind the use of Javanese language by teacher and student in the learning process is student's lack of Indonesian language vocabulary. In addition, teacher also uses the language unwittingly.

Factors to code-mixing are (1) habit factor, (2) spontaneity factor, (3) intentional factor, (4) learning material, and (5) language acquisition. Factors to code-switching are (1) the choice of hearer, (2) changing topics, (3) feeling angry, (4) the influence of partner's language, (5) class situation, (6) religious factor, and (7) factor of language acquisition. The function of code-mixing include: (a) transferring meaning, (b) clarifying speech, (c) explaining learning material, and (d) strengthening speech. The function of code-switching include: (a) performing good communication, (b) strengthening order, (c) giving advice, (d) giving questions, (e) repeating the meaning of the speech, (f) reminding, (g) clarifying speech, and (h) growing familiarity. The positive side of this phenomenon can be an effective way to deliver lesson to students because both teachers and students understand the languages. However, the use of Javanese language at class can ruin the grammatical aspect of Indonesian language, which then trigger code-mixing, code-switching, and interference which creates an informal learning situation.

\section{References}

Anwar, S. (2013). Penggunaan bahasa Jawa anak usia sekolah dasar di desa tanjungrejo kecamatan bayan kabupaten purworejo. Jurnal Bahasa, Sastra, dan Budaya Jawa, 1(3), 36-42. 
Ariffin, K. D. M. S. H. (2011). Code-switching and code-mixing of English and Bahasa Malaysia in content-based classrooms: Frequency and attitudes. The Linguistics Journal, 5(1), 220-247.

Ayeomoni, M. O. (2006). Code-switching and code-mixing: Style of language use in childhood in Yoruba speech community. Nordic Journal of African Studies, 15(1), 90-99.

Brice, A., \& Anderson, R. (1999). Code mixing in a Young bilingual child. Communication Disorders Quarterly, 2l(1), 17-22. http://dx.doi.org/10.1177/152574019902100103

Carlson, S. M., \& Meltzoff, A. N. (2008). Bilingual experience and executive functioning in young children. Developmental Science, 11(2), 282-298.http://dx.doi.org/10.1111/j.1467-7687.2008.00675.x

Chung, H. H. (2006). Code switching as a communication strategy: A case study of Korean-English bilinguals. Bilingual Research Journal: The Journal of the National Association for Bilingual Education, 30(2), 293-307. http://dx.doi.org/10.1080/15235882.2006.10162878

David, C. S. (2008). Understanding mixed code and classroom code-switching: Myths and realities. New Horizons in Education, 5(6), 75-87.

Faltis, C. J. (1989). Code-switching and bilingual schooling: An examination of Jacobson's new concurrent approach. Journal of Multilingual and Multicultural Development, 10(2), 117-127. http://dx.doi.org/10.1080/01434632.1989.9994368

Gulzar, M. A. (2010). Code-switching: Awareness about Its utility in bilingual classrooms. Bulletin of Education and Research, 32(2), 23-44.

Gutiérrez-Clellen, V. F., Cereijido, G. S., \& Leone, A. E. (2009). Code-switching in bilingual children with specific language impairment". International Journal of Bilingualism, 13(1), 91-109. http://dx.doi.org/10.1177/1367006909103530

Hamdani, F. (2012). The influence of gender in determining the language choice of teenagers: Sundanese versus bahasa. International Journal of Basic and Applied Science, 1(1), 40-43.

Irawati, E. S. (2012). Karakteristik bahasa Indonesia tuturan siswa kelas 1 SDN Kesatrian 1 Malang dalam interaksi belajar mengajar. Jurnal Bahasa dan Sastra Indonesia, 1(1), 1-12.

Jegede, O. O. (2012). Role of code switching in multilingual public primary school in Ile-Ife, Nigeria. American Journal of Linguistics, 1(3), 40-46. http://dx.doi.org/10.5923/j.linguistics.20120103.04

Malone, S., \& Paraide, P. (2011). Mother tongue-based bilingual education in Papua New Guinea. International Review of Education, 57(5), 705-720. http://dx.doi.org/10.1007/s11159-011-9256-2

Moleong, L. J. (2002). Metodologi penelitian kualitatif. Bandung: Remaja Rosdakarya Offset.

Muharam, R. (2011). Alih kode, campur kode, dan inteferensi yang terjadi dalam pembicaraan bahasa Indonesia dan bahasa Melayu Ternate. Jurnal Pedagogik Sekolah Dasar, Edisi Khusus(1), 197-207.

Ohoiwutun, P. (2002). Sosiolinguistik: Memahami bahasa dalam konteks masyarakat dan kebudayaan. Jakarta: Kesain-Blanc.

Pagett, L. (2006). Mum and dad prefer me to speak Bengali at home: Code switching and parallel speech in a primary school setting. Literac, 40(3), 137-145. http://dx.doi.org/10.1111/j.1467-9345.2006.00424.x

Patton, M. Q. (1984). Qualitative evaluation methods. Beverly Hills, CA: Sage Publications.

Qing, X. (2012). A tentative analysis of code-switching in college bilingual education. Gale Education, Religion and Humanities Lite Package, Cross-Cultural Communication, 8(4), 30-33. http://dx.doi.org/10.3968/j.ccc.1923670020120804.1583

Saddhono, K. (2004). Etnik madura: Perspektif integrasi linguistik kultural. Surakarta: Pustaka Cakra.

Saddhono, K. (2007). Oreng madure dan wong solo. Surakarta: UNS Press dan Depdiknas.

Saddhono, K. (2013). Fenomena pemakaian bahasa Jawa sebagai bahasa ibu pada sekolah dasar kelas rendah di kota Surakarta: Sebuah kajian sosiolingustik. Surakarta: Sebelas Maret University.

Sudaryanto. (1995). Linguistik: Identitasnya, cara penanganan obyeknya, dan hasil kajiannya. Yogyakarta: Duta Wacana University Press.

Sugiyono. (2012). Metode penelitian pendidikan: Pendekatan kuantitatif, kualitatif, dan $R \& D$. Bandung: Alfabeta. 
Sutopo. (2002). Metodologi penelitian kualitatif. Surakarta: Sebelas Maret University Press.

Suwito. (1985). Sosiolinguistik. Surakarta: Sebelas Maret University.

Yulianti, L. (2013). Campur kode dalam proses belajar-mengajar di madrasah tsanawiyah negeri satui. Jurnal Bahasa dan Sastra, 3(2), 1-11.

\section{Copyrights}

Copyright for this article is retained by the author(s), with first publication rights granted to the journal.

This is an open-access article distributed under the terms and conditions of the Creative Commons Attribution license (http://creativecommons.org/licenses/by/3.0/). 